\title{
Клініко-морфологічні особливості гастроінтестінальних стромальних пухлин
}

\author{
${ }^{1}$ Харківська медична академія післядипломної освіти \\ ${ }^{2} Д У$ «Національний інститут раку», Київ \\ Одержано 29.06.2021 \\ Прийнято до друку 24.09.2021 \\ DOI: 10.32471/clinicaloncology.2663-466X.43-3.28201
}

\begin{abstract}
Вступ. Гастроінтестінальні стромальні пухлини (ГІСТ) є одними з мезенхімальних пухлин шлунково-кишкового тракту, які виявляють найчастіше. Зазвичай вони мають індолентний перебіг, але в деяких випадках можуть мати злоякісні характеристики. Мета. Вивчити основні клініко-морфологічні особливості ГІСТ різних гістотипів та локалізацій. Матеріали та методи. Ретроспективний аналіз історій хвороб, гістологічних препаратів забарвлених гематоксиліном-еозином та імуногістохімічних препаратів, забарвлених CD117, CD34, DOG-1, SMA та CD56 100 первинних ГICП, від пацієнтів, що пройшли оперативне лікування з приводу цих пухлин за період 2013-2019 рр. та щодо яких була інформація в історії хвороб стосовно перебігу захворювання мінімум протягом року після оперативного втручання. Результати. За локалізацією випадки ГІСП поділилися на ГІСП тонкого кишечнику (38\%), ГІСП шлунка (34\%), 27\% ГІСП товстої кишки та $1 \%$ (1 пухлина) ГІСП стравоходу. Епітеліоїдні ГICП мали лише шлункову локалізацію, не експресували CD34, мали вогнищеву слабку експресію CD117 та слабку експресію CD56 в окремих пухлинних клітинах. ГICП нешлункової локалізації характеризувалися веретеноклітинною будовою. ГІСП дванадцятипалої кишки відмічають у $5 \%$ усіх досліджених ГІСП та на доопераційному етапі були діагностовані як карциноми голівки підшлункової залози. ГІСП порожньої та клубової кишки в 100\% випадків мали розмір більше 5 см, серед цієї групи виявляли найбільше пухлин, що були вперше виявлені на стадії органних метастазів. Більше половини пацієнтів з ГІСП тонкокишкової локалізації мали безсимптомний перебіг пухлинного процесу, у третини спостерігалася анемія. ГІСП товстої кишки відмічали в $27 \%$ всіх досліджених ГІСП, 92,6\% пухлин цієї локалізації мали розмір менше 5 см, а в третині випадків поєднувалися з іншими онкологічними процесами. Усі ГICП нешлункової локалізації експресували CD117, DOG-1 та в 68,2\% випадків експресували CD34. Слабка експресія SMA спостерігалася в 12 пухлинах (12\%), всі вони мали веретеноклітинну будову. ГІСП нешлункової локалізації давали рецидиви в період від 1 до 3 років частіше, ніж шлункові ГІСП. Висновки. Тонкокишкові ГІСП зазвичай мають більші розміри, можуть бути безсимптомними та мають більш агресивний перебіг. Товстокишкові ГІсп у нашій виборці відмічали в 5 разів частіше, ніж це наведено ВООЗ, та в третині випадків поєднувалися з іншими пухлинними захворюваннями, що може бути використано для подальших досліджень онкогенезу цих пухлин. Майже всі нешлункові ГICП мали веретеноклітинну будову та експресували CD117 та DOG-1. Епітеліоїдним ГІСп була притаманна шлункова локалізація та слабка, вогнищева експресія CD117 і негативна реакція з CD34.
\end{abstract}

Ключові слова: гастроінтестінальна стромальна пухлина; епітеліоїдна ГІСП; веретеноклітинна ГІCП; прогноз; CD117; DOG-1.

\section{вступ}

ГІСП належать до рідкісних пухлин шлунково-кишкового тракту [1], однак серед мезенхімальних пухлин травної системи їх частка є найбільшою [2]. Ці пухлини зазвичай мають індолентний перебіг і їх діагностують, коли вони мають вже значні розміри [3]. На теперішній час досі вивчають злоякісний потенціал цих пухлин $[4,5]$, особливу увагу в прогнозі перебігу ГІСП приділяють їх розміру, локалізації та мітотичній активності [2, 6]. При цьому лише один показник - мітотична активність $€$ гістологічним критерієм. В останній класифікації пухлин травного тракту ВООЗ, 2019, усі ГІСП кодовані як злоякісні - 8936/3 [2].

Іншим важливим питанням щодо ГІСП, крім прогнозування їх перебігу, є діагностика. Без гістологічного дослідження за даними лише комп'ютерної томографії, магнітно-резонансної томографії, ендоскопії та клінічної симптоматики ГІСП можуть бути помилково розцінені як аденокарциноми або лейоміоми $[7,8]$. При рутинному гістологічному дослідженні 3 гематоксиліном та еозином встановлення діагнозу також може бути проблемою: веретеноклітинні ГІСП у залежності від мітотичної активності можуть бути розцінені як лейоміоми або лейоміосаркоми і навіть інколи - шванноми [2, 8, 9], а епітеліоїдні ГІСП шлунка слід диференціювати з гломусними пухлинами, карциномами та нейроендокринними пухлинами [7, 10]. Для точної верифікації діагнозу потрібне використання методів імуногістохімії, але важливим є розумний вибір діагностичної панелі маркерів. Наприклад, раніше для імуногістохімічної діагностики ГІСП широко використовувалося таке антитіло, як CD34 [11], але слід зазначити, що цей маркер експресується не в усіх ГІСП [8] і не є специфічним маркером цих пухлин [12], тому наразі його виключено з первинної діагностичної панелі для ГІСП [9]. Більш чутливими є такі маркери як CD117 та DOG-1, з яких останній є специфічним для ГІСП [2,7,9]. У разі відсутності експресії CD117, збережена експресія DOG-1 $є$ вирішальною для встановлення діагнозу ГІСП [13]. Також рідко можуть виникати ГІСП, негативні до цих двох маркерів [2,7] і в такому разі саме досвід патоморфолога і добре знання клініко-морфологічних характеристик ГІСП буде вирішальним для призначення молекулярного дослідження пацієнтам з підозрою на ГІСП та, як наслідок, вибору правильної стратегії лікування цих пацієнтів.

\section{META}

Вивчення клініко-морфологічних особливостей ГІСП різної локалізації та різного гістотипу.

\section{ОБ 'ЄКТ І МЕТОДИ}

Об’єктом дослідження були 100 вперше виявлених гастроінтестінальних стромальних пухлин пацієнтів, що були прооперовані з цього приводу в період 2013-2019 pр. у наступних лікувальних закладах: ДУ «Інститут медичної радіології та онкології ім. С.П. Григор'єва» НАМН України, м. Харків; ДУ «Інститут загальної та невідкладної хірургії ім. В.Т. Зайцева Національної академії медичних наук України», м. Харків, та Національний інститут раку, м. Київ. 3 усіма вищевказаними закладами є чинні договори щодо 
наукової співпраці. Предметом дослідження були клінікоморфологічні особливості ГІСП. 3 історій хвороб нами вивчалися наступні параметри: стать, вік хворого на ГІСП, розмір пухлини за даними протоколів операції, локалізація та вид оперативного втручання, стадія за TNM, наявність хіміотерапії та дані щодо наявності або відсутності рецидиву мінімум протягом року після первинної операції, максимум протягом 3 років, також аналізувалися такі дані як наявність синхронного або метахронного іншого пухлинного процесу у пацієнта. Окремо аналізували гістологічні висновки, імуногістохімічні висновки, гістологічні препарати забарвлені гематоксиліном та еозином, та імуногістохімічні препарати пухлин. Окремо, за необхідності додаткового дослідження з імуногістохімічними маркерами, якщо таке не проводилося, використовували парафінові блоки з фрагментами пухлин. 3 гістологічних та імуногістохімічних висновків аналізували макроскопічні характеристики пухлини, їх гістологічну будову, реакцію з такими маркерами, як CD117, CD34, DOG-1 та SMA. Під час перегляду гістологічних препаратів додатково перераховували мітотичну активність у 5 мм² $^{2}$. Для підрахунку мітотичної активності гістологічні препарати пухлин вивчалися в найбільш активній зоні за збільшення $\times 1000$ в 50 полях зору.

Пухлини були розподілені на категорії ризику прогресії згідно з рекомендаціями Інститут патології збройних сил США (United States Armed Forces Institute of Pathology - AFIP), наведеними в останній гістологічній класифікації пухлин травної системи ВОО3 (2019) [2]. Отримані дані наведено в таблиці.

Імуногістохімічне дослідження виконували у тих випадках, коли його не було виконано в повному обсязі з наступними маркерами: CD117 (1:300, поліклон, TermoScientific), CD34 (1:50, QBEnd 10, Dako), DOG-1 (1:100, клон SP31, TermoScientific), SMA (1:300, клон 1A4, TermoScientific) та CD56 (1:100,123C3,Dako).

Усі скельця з гістологічними та імуногістохімічними зрізами оцінювали за допомогою мікроскопа Primo Star (Carl Zeiss), об'єктиви $\times 4, \times 10, \times 40, \times 100$ з подальшою обробкою за допомогою програми «АхіоCam» 3 використанням камери ERc5s.

Оцінка ступеня вираженості імуногістохімічної мітки CD117, CD34, DOG-1, SMA та CD56 в пухлинних клітинах оцінювалася напівкількісним методом, де: «-»- експресія відсутня; «+»- експресія слабо виражена, вогнищева; «++»помірна експресія; «+++» - сильна експресія маркера.

Для аналізу кількісних показників нами було використано методи біостатистики. Для підвищення точності оцінки отриманих результатів зв'язок між ознаками визначався з використанням непараметричного критерію хі-квадрат Пірсона. У малих групах для оцінки зв'язку між ознаками також використовували точний критерій Фішера. Для опису якісних характеристик застосовувався екстенсивний показник (\%). Первинні таблиці для обчислення були сформовані в програмі «Microsoft Exel 2013» 3 подальшою статистичною обробкою в програмі «MedCalc».

\section{РЕЗУЛЬТАТИ}

Нами було досліджено 100 випадків первинних гастроінтестінальних стромальних пухлин, що були відібрані за період

Таблиця. Розподіл первинних ГІСП на категорії ризику прогресії з урахуванням локалізації

\begin{tabular}{lcccc}
\hline Категорія & $\begin{array}{c}\text { Кількість мі- } \\
\text { тозів/5 ммз }\end{array}$ & $\begin{array}{c}\text { Розмір пух- ГІСП шлунка } \\
\text { лини (см) }\end{array}$ & $\begin{array}{c}\text { ГІСП інших } \\
\text { локалізацій }\end{array}$ & $\begin{array}{c}\text { (n) } \\
\text { (n) }\end{array}$ \\
\hline 1 & & $\leqslant 2$ & 3 & 2 \\
2 & $\leqslant 5$ & $>2$ до $\leqslant 5$ & 12 & 11 \\
$3 \mathrm{a}$ & & $>50 \leqslant 10$ & 5 & 8 \\
$3 \mathrm{~b}$ & & $\leqslant 10$ & 1 & 3 \\
4 & & $>2$ до $\leqslant 5$ & 5 & 2 \\
5 & $>5$ & $>5$ до $\leqslant 10$ & 6 & 17 \\
$6 \mathrm{a}$ & & $>10$ & 2 & 8 \\
$6 \mathrm{~b}$ & & & & \\
\hline
\end{tabular}

2013-2019 рр. 65\% пацієнтів були жінками, 35\% - чоловіками. Середній вік пацієнтів значущо не відрізнявся та становив $57 \pm 7,48$ для жінок і 56,6 $\pm 8,2$ для чоловіків.

3і 100 ГІСП, що були досліджені, у 37 (37\%) зафіксували рецидив у період від 1 до 3 років. У нашій добірці рецидиву в період від 1 до 3 років не відмічали в наступних групах: ГІСП будь-якої локалізації з категорії 1, та ГІСП з категорії 4 (у цій категорії у нас були відсутні пухлини шлункової локалізації), а також шлункові ГІСП з категорії 5 (рис. 1). У цілому шлункові ГІСП як з низькою, так і з високою мітотичною активністю рецидували рідше, ніж ГІСП нешлункової локалізації (19 та 25\% 3 кількістю мітозів $\leqslant 5 / 5 \mathrm{Mm}^{2}, 30,8$ та 54,8\% 3 кількістю мітозів

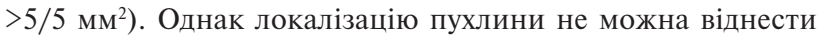
до статистично достовірного фактора прогресії, бо розрахунок критерію Пірсона як для групи з низькою, так і для групи з високою мітотичною активністю вказує на відсутність статистичної достовірності цього показника (Xi-квадрат Пірсона $=0,632$, $\mathrm{p}>0,05$ та Хі-квадрат Пірсона $=0,131, \mathrm{p}>0,05$ відповідно).

За локалізацією випадки ГІСП поділилися на ГІСП тонкого кишечнику (38\%), ГІСП шлунка (34\%), 27\% ГІСП товстої кишки та 1\% (1 пухлина) ГІСП стравоходу.

ГІСП шлункової локалізації в нашій добірці становили 34\% від загальної кількості ГІСП, розподілення випадків цієї онкопатології в різних ділянках шлунка надано на рис. 2.

У $14,7 \%$ (5 випадків) пухлини мали мультивузловий характер росту. Макроскопічно у 23,5\% (8 випадків) відмічалося виразкування слизової оболонки над пухлиною, що клінічно проявлялося у пацієнтів хронічною шлунковою кровотечею. 20,6\% (7 випадків) пухлин мали в середині кістозні порожнини. Усі пухлини розміром більше 5 см мали крововиливи на розрізі. Якщо спиратися на протоколи операцій, резекція пухлин була виконана в повному обсязі (R0). Тотальну гастректомію проведено лише у 20,6\% пацієнтів, в інших 79,4\% ГІСП шлунку виконано резекцію пухлини з частиною шлунка.

Гістологічно ГІСП шлунка поділялися на епітеліоїдні (6-17,6\%), веретеноклітинні (26-76,5\%) та змішані (2-5,9\%). Для більшості пухлин відмічали мітотичну активність $\leqslant 5$ мітозів $/ 5$ мм² $^{2}(61,8 \%)$. Усі виявлені пухлини шлунка з високою мітотичною активністю мали розмір більше $2 \mathrm{~cm}$.

Епітеліоїдні ГІСП в нашій виборці мали світлу цитоплазму та округлі клітини (2 одиниці) або складалися 3 кластерів дрібних клітин (рис. 3).

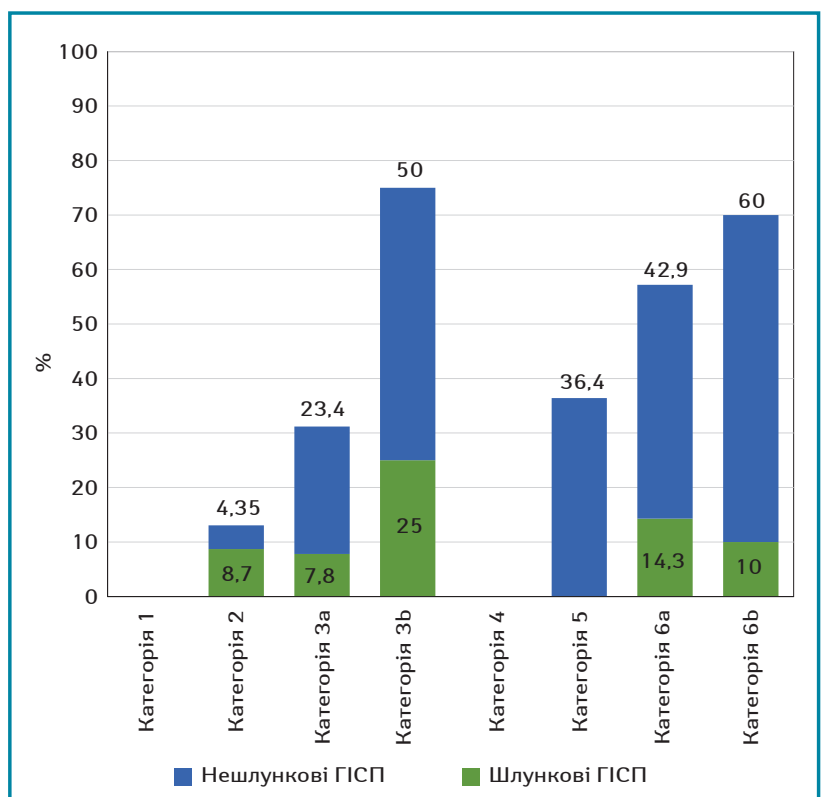

Рис. 1. Випадки рецидивування ГІСП в період від 1-3 років після первинної операції в залежності від категорії ризику 


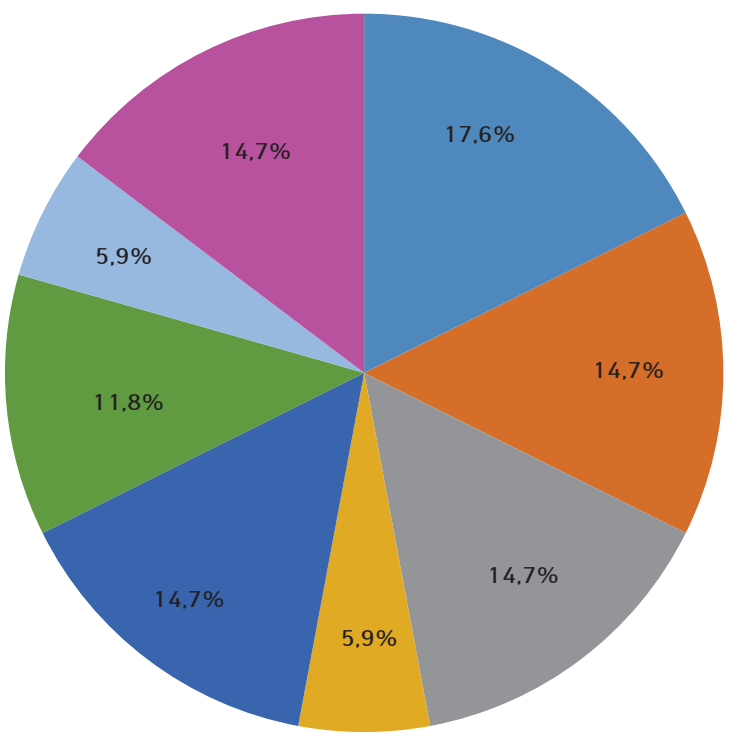

$$
\begin{aligned}
& \text { Передня стінка } \\
& \text { Мала кривизна } \\
& \text { Дно } \\
& \text { Антрум }
\end{aligned}
$$$$
\text { — Задня стінка }
$$$$
\text { Велика кривизна }
$$$$
\text { - Кардія }
$$

口 Пухлина виходить за межі однієї локалізації

Рис. 2. Графік розподілення ГІСП шлунка в залежності від локалізації

У всіх випадках епітеліоїдних ГІСП точний діагноз було встановлено тільки після проведення імуногістохімічного дослідження. Досліджені нами ГІСП експресували CD117 та DOG-1. Однак у всіх епітеліоїдних пухлинах, що дали рецидиви (3 одиниці), експресія CD117 була слабкою або мала гетерогенний характер (рис. 4), порівняно з експресією DOG-1 (рис. 5), яка була більш виразною. У злоякісних ГІСП епітеліоїдної та змішаної будови в деяких епітеліоїдних пухлинних клітинах спостерігалася експресія CD56 (рис. 6). Досліджені нами епітеліоїдні ГICП не експресували CD34 в пухлинних клітинах. Веретеноклітинні ГІСП шлунка переважно мали наступні гістологічні особливості: клітини організовані в палісадні структури з помірною вакуолізацією цитоплазми (рис. 7). Усі ГІСП добре експресували DOG-1, однак експресія CD117 у частині випадків мала нерівномірний характер, інтенсивність забарвлення була слабкою в ГІСП, що рецидували, так само як і в епітеліоїдних ГІСП. CD34 експресувався в поодиноких пухлинних клітинах.

У 2 пацієнтів з ГІСП шлунка синхронно була наявна також аденокарцинома шлунка.

ГІСП нешлункової локалізації становили 66\% досліджених нами пухлин такого типу та поділялися на наступні категорії: ГІСП дванадцятипалої кишки (7,5\%), ГІСП інших відділів тонкої кишки (50\% від всіх ГІСП нешлункової локалізації та 33\% від всіх досліджених ГІСП), ГІСП товстої кишки (41\% усіх ГІСП нешлункової локалізації та 27\% усіх досліджених ГІСП), ГІСП стравоходу (1 пухлина/1,5\%).

Макроскопічно пухлинам були притаманні наступні характеристики: куляста форма, щільність, 13,6\% пухлин (9 одиниць) мали кістозні порожнини, 7,6\% (5 пухлин) мали ніжку та проростали в черевну порожнину. 30,3\% (20 пухлин) були більше 5 см у діаметрі та мали некрози чи крововиливи.

Клінічними проявами пухлин дванадцятипалої кишки були: механічна жовтяниця, нудота, біль в епігастрії. Попередній клінічний діагноз при ГІСП дванадцятипалої кишки був пухлина головки підшлункової залози або заочеревинного простору. Інтраопераційно пухлина мала капсулу та росла зі стінки нисхідного відділу дванадцятипалої кишки з розповсюдженням на головку підшлункової залози. Операція в усіх випадках проводилася в обсязі R0,

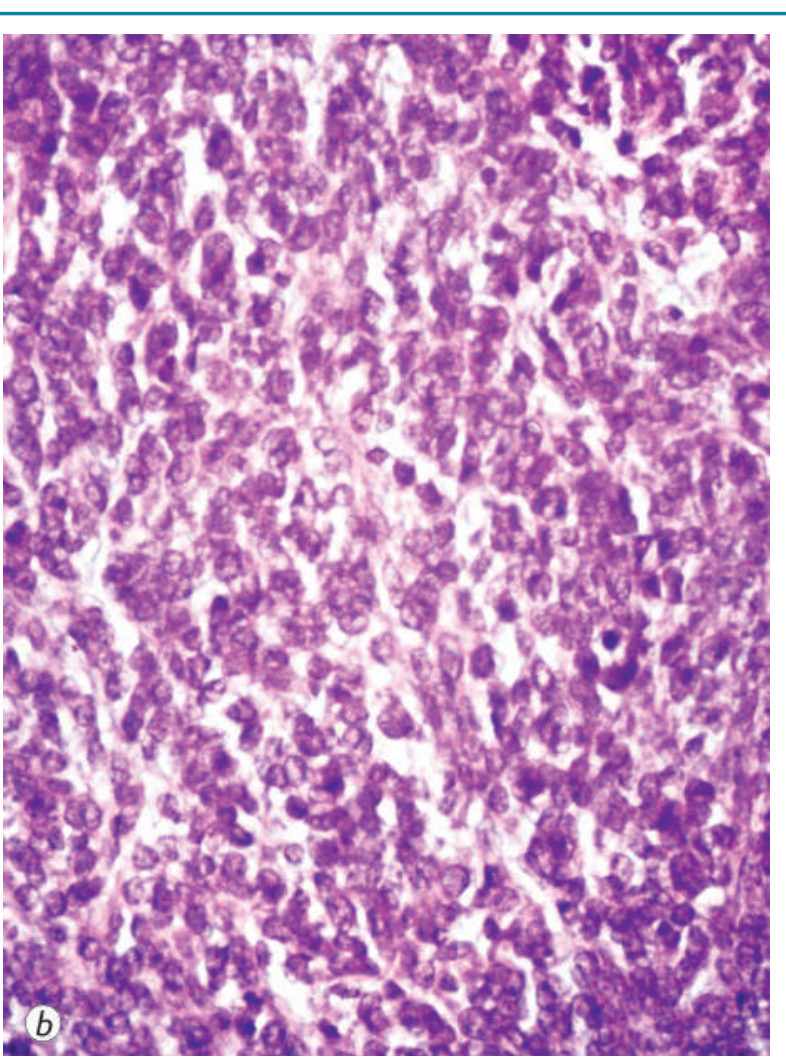

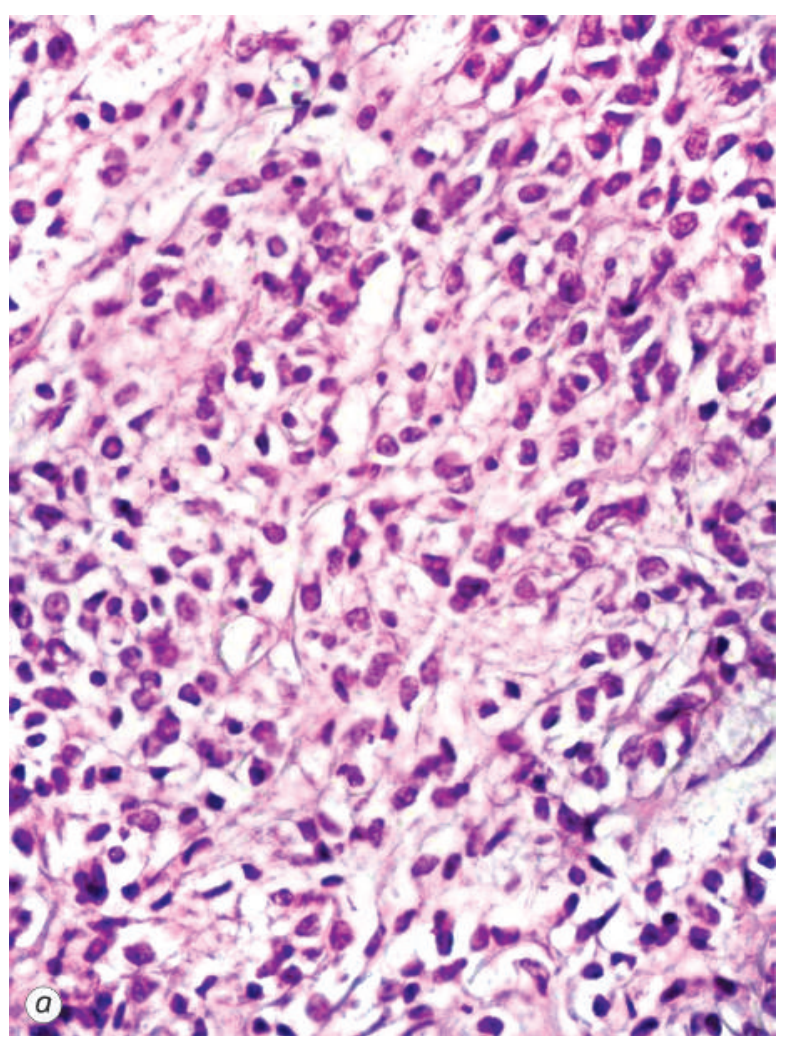

Рис. 3. Епітеліоїдні ГІСП шлунка. Забарвлення гематоксиліном/еозином, ×1000: $a$ - зі світлою цитоплазмою; $b-3$ великою дрібних пухлинних клітин з вираженим ядром та майже відсутньою цитоплазмою, що організовані в щільні кластери 


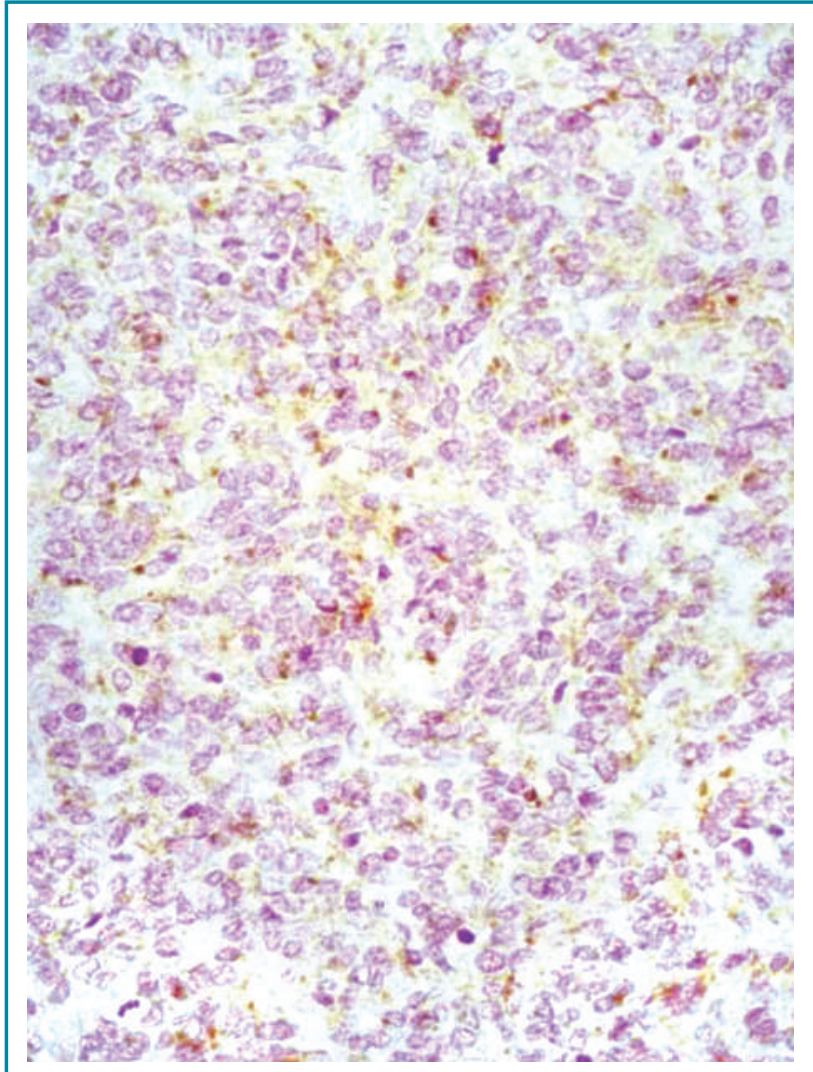

Рис. 4. Слабка вогнищева експресія CD117 в епітеліоїдній ГІСП шлунка, high grade, додаткове забарвлення гематоксиліном Майера, ×1000

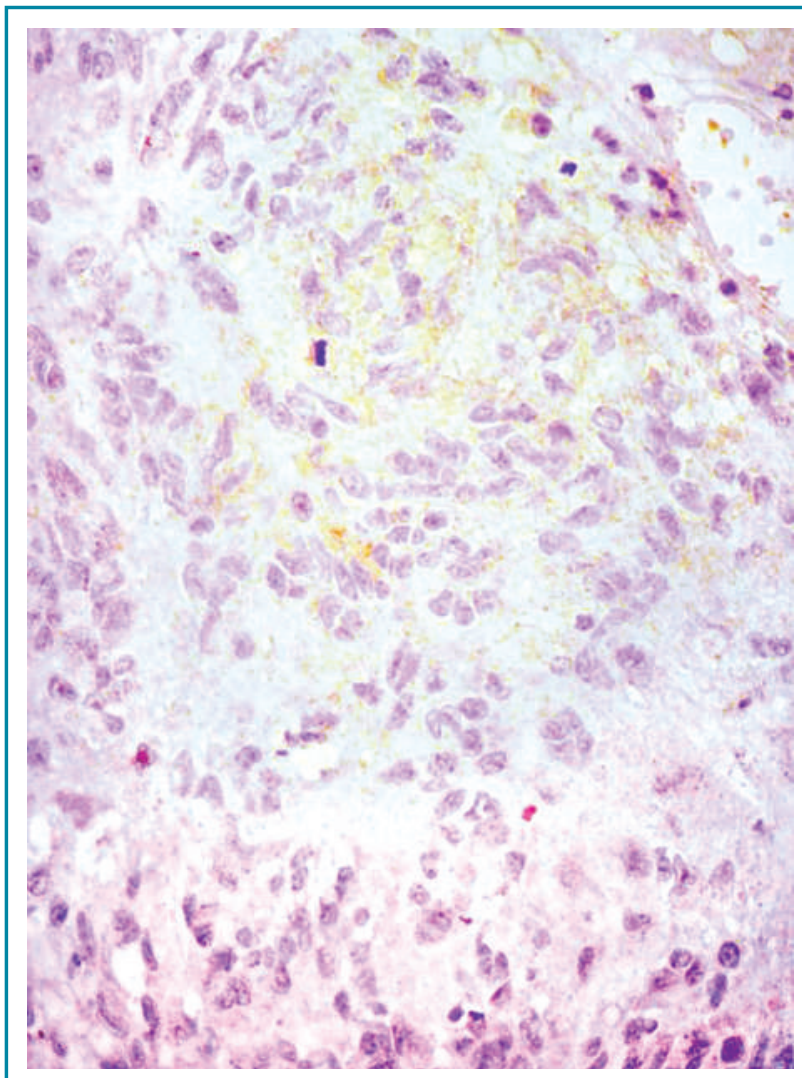

Pис. 6. Поодинока експресія CD56 в епітеліоїдній ГICП, high grade, безклітинні ділянки, додаткове забарвлення гематоксиліном Майера, ×1000

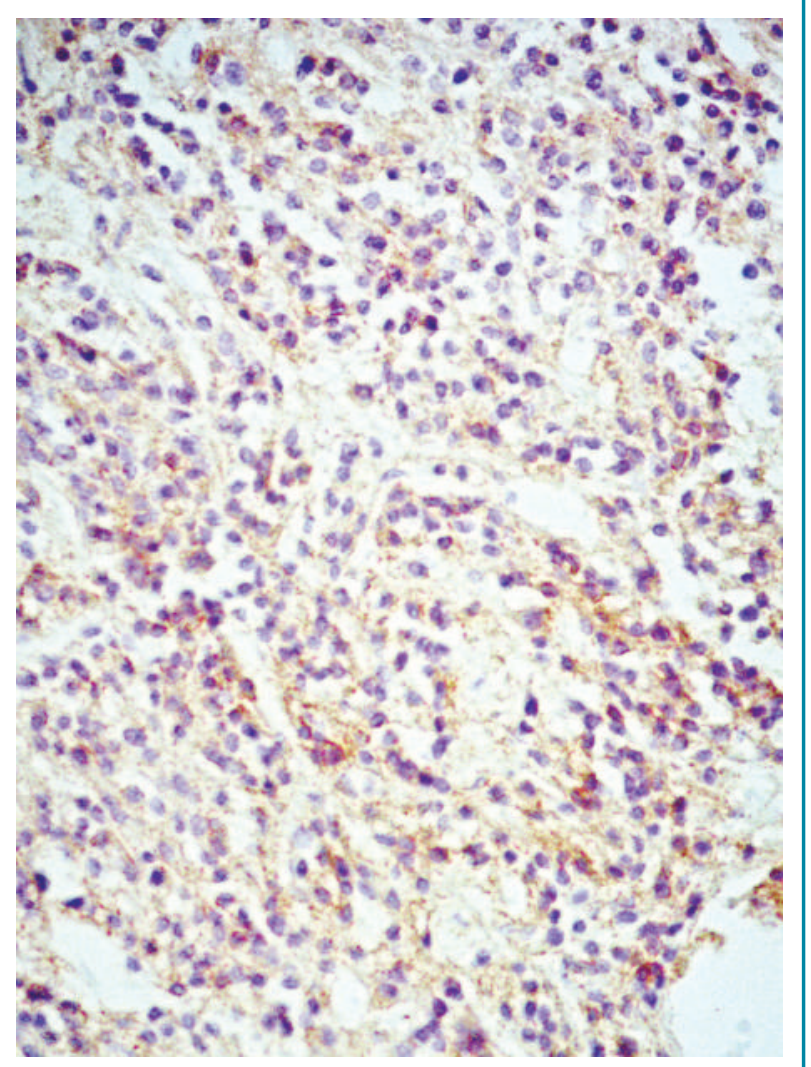

Рис. 5. Помірна експресія DOG-1 в епітеліоїдній ГICп шлунка, high grade, додаткове забарвлення гематоксиліном Майера, ×1000

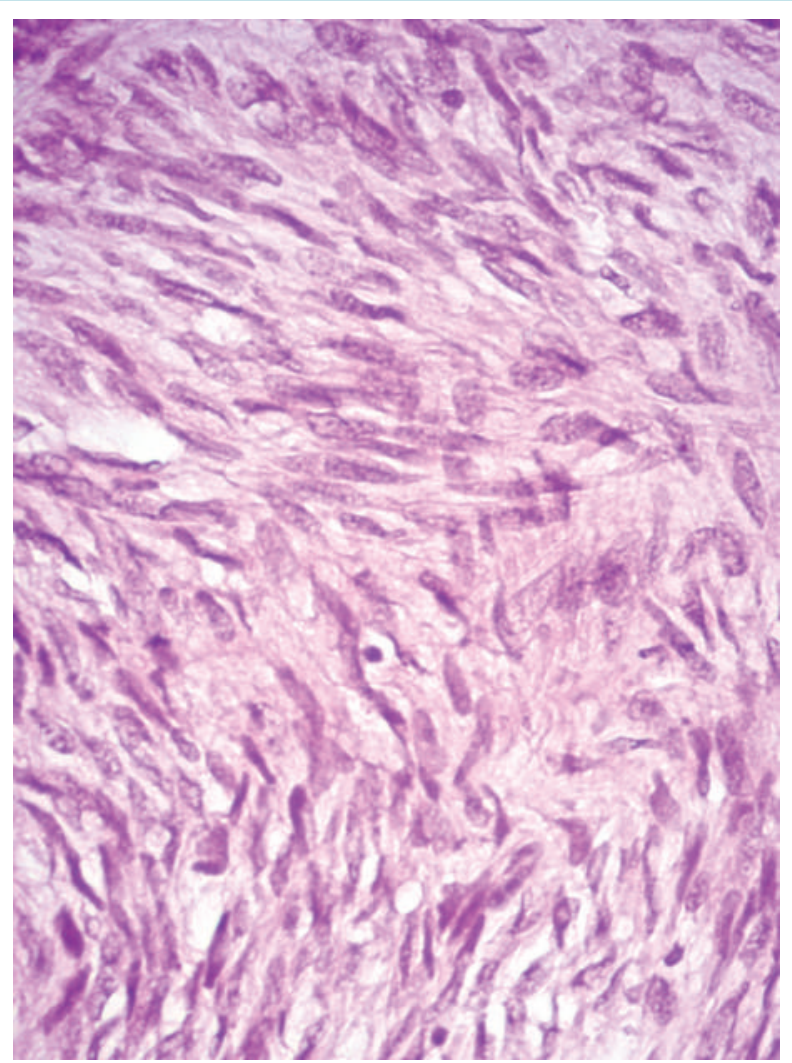

Рис. 7. Веретеноклітинна ГІСП шлунка, у цитоплазмі помітні дрібні вакуолі, забарвлення гематоксиліном/еозином, $\times 1000$ 
найчастіше виконувалася гастропанкреатодуоденальна резекція (3 випадки), атипова резекція дванадцятипалої кишки та пілорозберігаюча панкреатодуоденальна резекція виконувалися по 1 випадку відповідно.

Пухлини тонкої кишки в $100 \%$ випадків були більше 5 см, розповсюджувалися на брижу, у 24,2\% (8 випадків) у пухлинне утворення були втягнуті стінки двох різних ділянок кишки. У 7 випадках була виконана резекція тонкої кишки з пангістеректомією, в інших виконувалася резекція петлі тонкої кишки чи резекція петлі тонкої кишки та дуоденоєюнального згину. Операція в усіх випадках проводилася в обсязі R0. У 5 випадках пухлина мала багатовузловий характер росту. 54,5\% пацієнтів (18 осіб) відмічали безсимптомний перебіг захворювання, пухлинне утворення було виявлено під час профілактичного огляду. У майже третини пацієнтів $(30,3 \% / 10)$ спостерігалася анемія, періодичний біль у шлунку відмічали у 8 пацієнтів. 16 пухлин мали некрози та крововиливи. Зазвичай пухлина дещо звужувала просвіт кишки. Кісти відмічали у $24,2 \%$ пухлин (8 одиниць). У $36,4 \%$ пацієнтів (12 осіб) виявляли рецидив пухлини в період від 1 до 3 років, показник рецидивів був найвищим саме в групі ГІСП тонкої кишки, що пов'язано 3 тим, що всі вони мали значний розмір, та більш ніж половина $(51,5 \% / 17)$ проявляла мітотичну активність $>5 / 5 \mathrm{Mм}^{2}$.

Переважна більшість пухлин товстої кишки мала розмір менше 5 см (25 випадків/92,6\%) або незначно перевищували цей розмір (2 пухлини/7,4\%). Пухлини звужували просвіт кишки, мали кулясту форму та локалізувалися підслизово, у 26\% хворих (7 випадків) відмічено виразкування слизової оболонки та кровотечу. У 66,6\% пацієнтів (18 випадків) пухлини були знахідкою на профілактичному огляді. Пацієнти найчастіше не мали скарг, а якщо мали, то найпоширенішою була загальна слабкість. 33,3\% (9 пацієнтів) мали метахронне інше онкологічне захворювання: у 6 хворих відмічали колоректальний рак, у 3 - лейкоз.

Також була виявлена 1 пухлина стравоходу, яка мала діаметр $<2$ та низьку мітотичну активність. Макроскопічно вона мала кулясту форму, щільно-еластичну консистенцію білого кольору, гістологічно - змішану будову.

Усі ГІСП кишечнику незалежно від відділу мали веретеноклітинну будову. У 63,6\% відмічали мітотичну активність $>5 / 5$ мм² $^{2}$. Для пухлин 3 мітотичною активністю $\leqslant 5 / 5$ мм $^{2}$ були притаманні наявність еозинофільних колагенових мас - так званих скеноїдних волокон (рис. 8). Також досить розповсюдженим був міксоматоз та наявність без'ядерних ділянок, особливо притаманно це було для ГІСП з локалізацією в тонкому кишечнику (рис. 9).

Експресія CD117 та DOG-1 була вираженою чи помірною (рис. 10). У ГІСП з виразним міксоматозом та кістозним компонентом експресія CD117 була гетерогенною та відрізнялася на різних ділянках. У всіх випадах ГІСП з високою мітотичною активністю проводилося імуногістохімічне дослідження і точний гістологічний діагноз було встановлено тільки після нього. Найчастіше диференційну діагностику проводили з лейоміомами та лейоміосаркомами, особливо коли пухлинні вузли тісно прилягали до матки. Дві третини ГІСП (45 випадків/68,2\%) експресували також CD34 в пухлинних клітинах.

У 13,2\% пацієнтів (12 випадків) усіх досліджених веретеноклітинних ГІСП (91 випадок) відмічалася слабка експресія SMA, експресію цього маркера в епітеліоїдних та змішаних пухлинах не виявляли.

У протоколах операцій та гістологічних дослідженнях не було вказано, чи була ціла або ушкоджена капсула пухлини, хоча сучасні гайди щодо ГІСП вказують, що інтраопераційне порушення цілісності капсули пухлини є негативною прогностичною ознакою.

У сучасній гістологічній класифікації ГІСП, що представлена ВОО3, не надається значення стадіюванню ГІСП

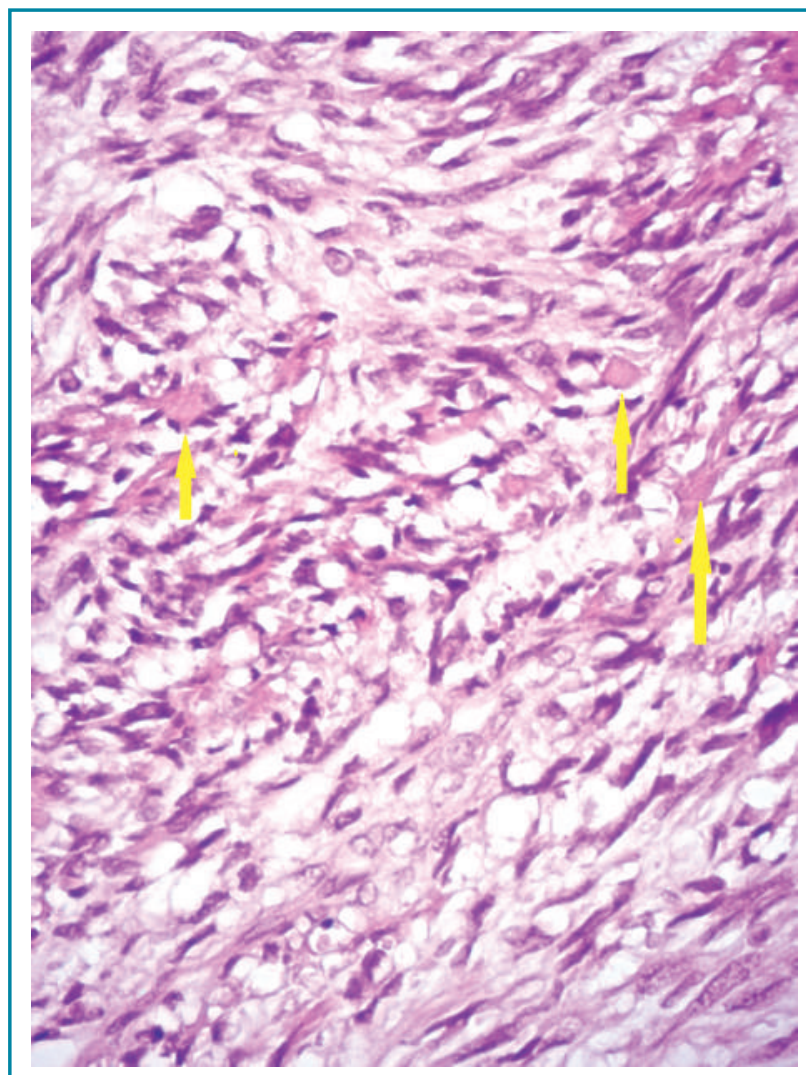

Рис. 8. Веретеноклітинна ГІСП кишки, стрілками показані скеноїдні волокна, забарвлення гематоксиліном/еозином, $\times 1000$

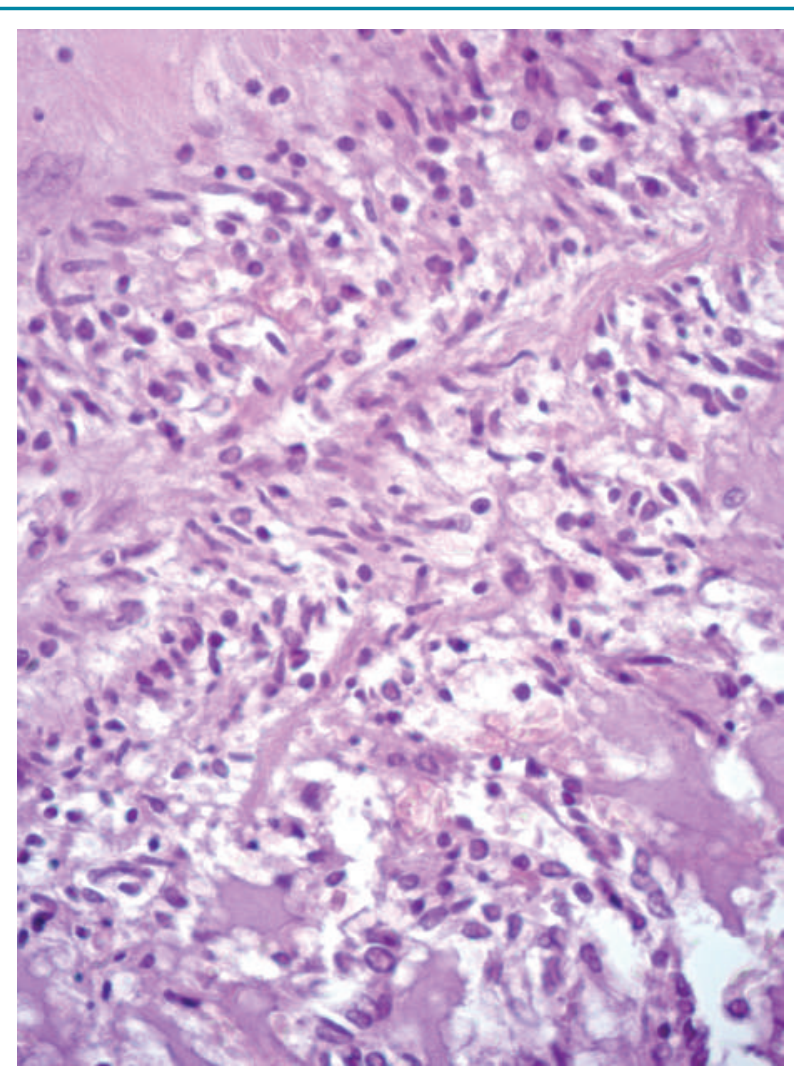

Рис. 9. Веретеноклітинна ГІСП кишки, з міксоматозом, некрозами та безклітинними ділянками, забарвлення гематоксиліном/еозином, $\times 1000$ 

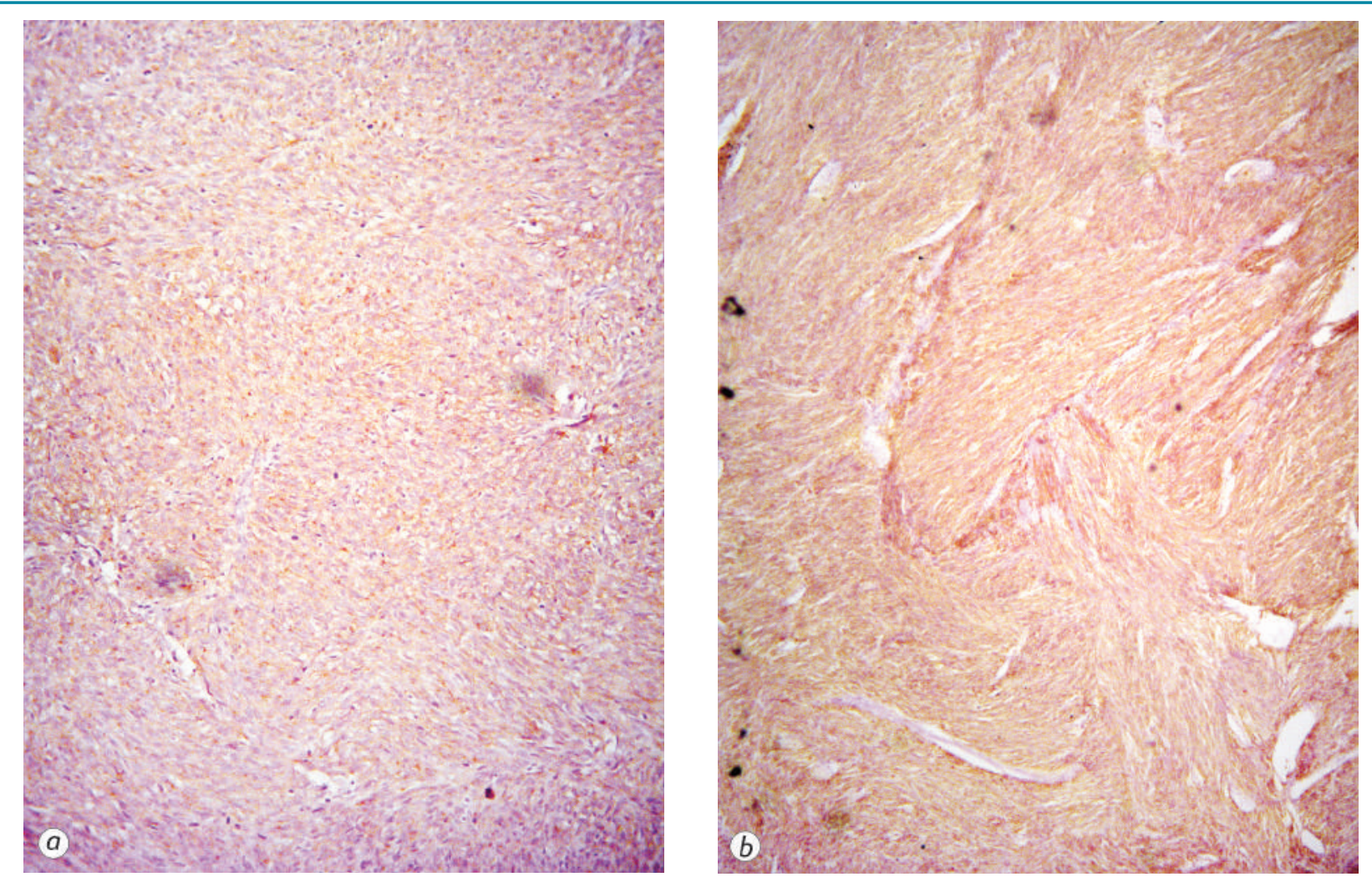

Рис. 10. Виразна експресія у веретеноклітинній ГICП кишечнику: a - CD117, b - DOG-1. Додаткове забарвлення гематоксиліном Майера, ×400

за TNM-класифікацією, оскільки стадія за ТNM не відповідає характеру перебігу пухлини. Однак дивлячись на те, що хірурги та онкологи досі використовують цю класифікацію для ГІСП, нами було проведено аналіз первинних ГІСП за ТNМ також. 50\% досліджених пухлин були виявлені на стадії Т4, 33\% - на стадії Т3 та лише $17 \%$ - на стадії Т2. Ураження регіональних лімфатичних вузлів було вказано лише в $5 \%$, метастази в органи - у $13 \%$. У всіх випадках метастазів відмічалися метастази в печінку, а у $3 \%$ пацієнтів були відмічені також метастази в очеревину та сальник. Найчастіше метастазували тонкокишкові ГІСП (9 з 13 пацієнтів).

Усі пацієнти з уперше виявленими метастатичними ГІСП та ГІСП з рівнем експресії більше 5 мітозів на 5 мм² $^{2}$ отримували після хірургічного лікування хіміотерапію іматинібом, також таке лікування отримали пацієнти з ГІСП нешлункової локалізації з розміром пухлини більше $5 \mathrm{~cm}$. Не зважаючи на терапію, рецидиви було виявлено як серед хворих, що отримали іматиніб, так і серед пацієнтів з відносно низьким ризиком рецидивів, що вказує на потребу в удосконаленні прогностичних критеріїв ГІСП з метою покращення індивідуальної терапії та уточнення прогнозу для пацієнтів.

\section{ОБГОВОРЕННЯ}

Отримані нами дані вказують на те, що епітеліоїдний характер будови притаманний ГІСП шлункової локалізації. У нашому дослідженні це 6 одиниць (17,6\% ГІСП шлунка або 6\% від загальної кількості досліджених ГІСП). Подібні дані наведені й в останній гістологічній класифікації пухлин травної системи, ВОО3, 2019, де сказано що епітеліоїдна будова відмічається в 20-25\% ГІСП шлункової локалізації і майже не притаманна для ГІСП іншої локалізації [2]. У нашому дослідженні в епітеліоїдних ГІСП спостерігалася слабка вогнищева експресія CD117, у той час як експресія DOG-1 була виразною. За даними C. Rizzardi та співавторів, такий тип експресії може бути притаманний епітеліоїдним ГICП з наявністю мутації в PGFRA [13], тому для правильної діагностики саме такого типу ГІСП важливим є використання в первинній панелі антитіл DOG-1 [9,13]. Також у нашому дослідженні було відмічено відсутність експресії CD34 в епітеліоїдних ГІСП та його слабка експресія у веретеноклітинних та змішаних ГІСП шлунка. А. Poveda та співавтори також вказують на те, що шлункові ГІСП рідше експресували CD34, ніж ГICП нешлункової локалізації [8], а останні діагностичні протоколи американської колегії патологів взагалі не включають CD34 до діагностичної панелі ГІСП [9]. Також у нашому дослідженні було відмічено, що ГІСП шлункової локалізації рецидивують рідше, ніж ГІСП інших локалізацій (19 та $25 \%$ з кількістю мітозів $\leqslant 5 / 5$ мм² $^{2}, 30,8$ та 54,8\% з кількіс-

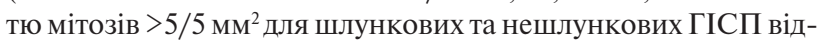
повідно). Хоча в нашому дослідженні ця відмінність не мала статистичної різниці, в гістологічній класифікації ВООЗ [2] та в роботах низки авторів описані такі ж самі тенденції [14, $15,16]$. Окремо слід відмітити наявність слабкої експресії CD56 у частині пухлинних клітин в епітеліоїдних ГІСП у нашому дослідженні. Подібні дані отримали A. Agaymy та P.H. Wünsch, які описали вогнищеву експресію CD56 у 50\% епітеліоїдних ГІСП [17].

Серед ГІСП нешлункової локалізації домінували ГІСП тонкої кишки, які в цілому були найпоширенішою групою таких онкологічних захворювань. Кількість ГІСП тонкокишкової локалізації не мала значних відмінностей від світових даних: $38 \%$ у нашій виборці та $30 \%$ за даними ВООЗ [2]. Однак у нашому дослідженні значно меншою була кількість шлункових ГІСП - 34\% порівняно з 54\% за даними ВООЗ.

Для усіх нешлункових ГІСП була притаманна веретеноклітинна будова, що співпадає з даними, наданими C.D. Fletcher [10] та ВОО3 [2]. Для ГІСП нешлункової локалізації була характерна виразна експресія CD117 та DOG-1, a 68,2\% цих пухлин експресували CD34. Отримані дані цілком відповідають світовим $[2,7,10]$. ГІСП з локалізацією в порожній чи клубовій кишці мали найбільший розмір порівняно з ГІСП інших локалізацій та безсимптомний перебіг більше ніж у по- 
ловині $(54,1 \%)$ випадків. Беручи до уваги те, що розмір пухлини є одним з незалежних факторів рецидивування та злоякісного переродження пухлини [2], важливим $є$ питання профілактичних оглядів з метою виявлення безсимптомних пухлин на ранніх стадіях. Окремо нами були виділені ГІСП з локалізацією в дванадцятипалій кишці (5 випадків - 5\% від загальної кількості ГІСП та 7,5\% від кількості ГІСП нешлункової локалізації) Ця кількість співпадає з даними, наведеними в дослідженнях M. Miettinen та співавторів, де відсоток цих пухлин становив 4-5\% [18]. ГІСП дуоденальної локалізації в нашому дослідженні на передопераційному етапі за даними комп'ютерної томографії діагностувалися як злоякісні новоутворення головки підшлункової залози. Ряд авторів у своїх роботах також вказують на те, що встановлення попереднього діагнозу ГІСП або навіть мезенхімальної пухлини є викликом і майже в усіх випадках не можливе без гістологічного дослідження $[19,20]$. У нашому дослідженні кількість ГІСП товстої кишки значно відрізнялася від даних ВОО3 - 27\% у нас та $5 \%$ за даними ВОО3 [2]. Однак слід зазначити, що 66,6\% цих пухлин були знахідкою під час профілактичного огляду та більшість 3 них $(92,6 \%)$ мала розміри $\leqslant 5$ см. Також слід зазначити, що в цій групі пухлин була виявлена найбільша частка пацієнтів з метахронними іншими онкологічними процесами (9 пацієнтів - 33,3\% від кількості ГІСП товстокишкової локалізації). Таке спостереження потребує подальших досліджень з метою виявлення специфічних генетичних мутацій у пацієнтів з метахронними пухлинами, та, можливо, особливих шляхів онкогенезу ГІСП у них

Також у 13\% пацієнтів ГІСП було виявлено на етапі органних метастазів. Найчастіше метастазували тонкокишкові ГІСП (9 з 13 пацієнтів, 69,2\%). Це може бути пояснено тим фактом, що тонкокишкові ГІСП у нашій виборці мали найбільші розміри та у більше ніж половини з них $(51,5 \%)$ відмічали виразну мітотичну активність, а як відмічено в критеріях прогнозу, розмір, мітотична активність та нешлункова локалізація $є$ незалежними несприятливими факторами прогнозу [2, 6].

\section{ВИСНОВКИ}

1. Епітеліоїдна гістологічна будова притаманна ГІСП зі шлунковою локалізацією, для таких пухлин у нашому дослідженні був притаманний наступний імуногістохімічний профіль: DOG-1 (++/+++), CD117 (вогнищева слабка експресія), CD34 (-) та в епітеліоїдних ГІСП з високою мітотичною активністю слабка експресія CD56 в окремих пухлинних клітинах.

2. Для нешлункових ГІСП притаманна веретеноклітинна будова та виражена експресія CD117 та DOG-1, у 68,2\% відмічалася також експресія CD34. Ця група пухлин давала рецидиви в період від 1 до 3 років частіше ніж шлункові ГІСП (25 та $19 \%$ з кількістю мітозів $\leqslant 5 / 5$ мм² $^{2}, 54,8$ та $30,8 \%$ з кількістю мітозів $>5 / 5$ мм $^{2}$ відповідно), але ця різниця не була статистично значущою.

3. Тонкокишкові ГІСП були найбільш розповсюдженою групою ГІСП у нашому дослідженні (38\%). ГІСП порожньої та клубової кишки мали найбільші розміри, відзначалися безсимптомним перебігом у 54,5\% та анемією - у 30,3\%. Саме ця група ГІСП найчастіше виявлялася на етапі органних метастазів.

4. ГІСП стравоходу та ГІСП з локалізацією у дванадцятипалій кишці відмічали найрідше. На догістологічному етапі ГІСТ дванадцятипалої кишки помилково інтерпретувалися як карциноми головки підшлункової залози.

5. У нашому дослідженні ГІСП товстої кишки виявлялися значно частіше, ніж це вказано ВОО3 (27\% у нас та 5\% за даними ВОО3). Ці пухлини зазвичай мали безсимптомний перебіг та розмір менший або рівний 5 см та їх виявляли випадково. Саме в цій групі пухлин найчастіше спостерігалося поєднання ГІСП з іншими пухлинами (33,3\% від кількості ГІСП товстокишкової локалізації).

Інформація щодо конфлікту інтересів: відсутній.

Захист людини і тварин під час проведення наукового дослідження.
Дизайн дослідження та всі методи, використані в ньому, були затверджені Комісією з біоетики Харківської медичної академії післядипломної освіти та відповідають вимогам Гельсінської декларації. Із закладами, де виконувався відбір матеріалу, є чинні договори щодо науково-практичної співпраці.

\section{СПИСОК ВИКОРИСТАНОЇ ЛІТЕРАТУРИ}

1. Corless, C. \& Heinrich, M. (2008). Molecular Pathobiology of Gastrointestinal Stromal Sarcomas. Annual Review Of Pathology: Mechanisms Of Disease, 3(1), 557-586. doi: 10.1146/annurev.pathmechdis.3.121806.151538

2. Lokuhetty, D. (2019). Gastrointestinal stromal tumour. In: WHO Classification of Tumours: Digestive System Tumours, (5th ed., pp. 439-443). Lyon.

3. Akahoshi, K., Oya, M., Koga, T., \& Shiratsuchi, Y. (2018). Current clinical management of gastrointestinal stromal tumor. World Journal Of Gastroenterology, 24(26), 2806-2817. doi: $10.3748 /$ wjg.v24.i26.2806.

4. Corless, C. (2014). Gastrointestinal stromal tumors: what do we know now? Modern Pathology, 27(S1), S1-S16. doi: 10.1038/modpathol.2013.173.

5. Ren, C., Wang, S., \& Zhang, S. (2020). Development and validation of a nomogram based on CT images and 3D texture analysis for preoperative prediction of the malignant potential in gastrointestinal stromal tumors. Cancer Imaging, 20(1). doi: 10.1186/s40644-019-0284-7.

6. Chen, T., Xu, L., Ye, L., Qiu, H., Hu, Y., \& Liu, H. ... Yu, J. (2018). A new nomogram for recurrence-free survival prediction of gastrointestinal stromal tumors: Comparison with current risk classification methods. European Journal Of Surgical Oncology. doi: 10.1016/j.ejso.2018.12.014

7. Differential Diagnosis - Gastrointestinal Stromal Tumor (GIST) - Surgical Pathology Criteria - Stanford University School of Medicine. (2021). Retrieved from http://surgpathcriteria.stanford.edu/gitumors/ gist-gastrointestinal-stromaltumor/ differential-diagnosis.html.

8. Poveda, A., Garcia del Muro, X., López-Guerrero, J., Cubedo, R., Martínez, V., \& Romero, I. (2017). GEIS guidelines for gastrointestinal sarcomas (GIST). Cancer Treatment Reviews, 55, 107-119. doi: 10.1016/j.ctrv.2016.11.011.

9. Protocol for the Examination of Biopsy Specimens From Patients With Gastrointestinal Stromal Tumor (GIST). (2021). Retrieved from https://documents.cap.org/protocols/Stomach.GIST.Bx_4.2.0.0.REL_CAPCP.pdf.

10. Fletcher, C.D., Berman, J.J., Corless, C., Gorstein, F., Lasota, J., Longley, B.J.,

Weiss, S.W. (2002). Diagnosis of gastrointestinal stromal tumors: a consensus approach. Human Pathology, 33(5), 459-465. doi: 10.1053/hupa.2002.123545.

11. Miettinen, M., Sobin, L., \& Sarlomo-Rikala, M. (2000). Immunohistochemical Spectrum of GISTs at Different Sites and Their Differential Diagnosis with a Reference to CD117 (KIT). Modern Pathology, 13(10), 1134-1142. doi: 10.1038/modpathol.3880210.

12. Krasinskas, A., \& Goldsmith, J. (2011). Immunohistology of the Gastrointestinal Tract. Diagnostic Immunohistochemistry, 500-540. doi: 10.1016/b978-1-4160-5766-6.00018-2.

13. Rizzardi, C., Marzinotto, S., Avellini, C., Melato, M., \& Mariuzzi, L. (2012). A KIT-negative, DOG1-positive Epithelioid GIST of the Stomach Harboring a Novel PDGFRA Exon 14 Single Nucleotide Deletion. Anticancer Research, 32(5), 1775-1778.

14. Parab, T., DeRogatis, M., Boaz, A. Grasso, S., Issack, P., Duarte, D., Hinika, G.S. (2018). Gastrointestinal stromal tumors: a comprehensive review. Journal of Gastrointestinal Oncology, 10(1), 144-154. doi: 10.21037/jgo.2018.08.20.

15. Joensuu, H., Vehtari, A., Riihimäki, J., Nishida, T., Steigen, S., Brabec, P., Rutkowski, P. (2012). Risk of recurrence of gastrointestinal stromal tumour after surgery: an analysis of pooled population-based cohorts. The Lancet Oncology, 13(3), 265-274. doi: 10.1016/S1470-2045(11)70299-6.

16. Jones, R. (2014). Practical Aspects of Risk Assessment in Gastrointestinal Stromal Tumors. Journal of Gastrointestinal Cancer, 45(3), 262-267. doi: 10.1007/s12029-014-9615-x.

17. Agaimy, A., \& Wünsch, P. (2007). Distribution of neural cell adhesion molecule (NCAM/CD56) in gastrointestinal stromal tumours and their intraabdominal mesenchymal mimics. Journal Of Clinical Pathology, 61(4), 499-503. doi: 10.1136/jcp.2007.052696.

18. Miettinen, M., \& Lasota, J. (2006). Gastrointestinal stromal tumors: Pathology and prognosis at different sites. Seminars in Diagnostic Pathology, 23(2), 70-83. doi: 10.1053/j.semdp.2006.09.001

19. Du, H., Ning, L., Li, S., Lou, X., Chen, H., Hu, F., ... Xu, G. (2020). Diagnosis and Treatment of Duodenal Gastrointestinal Stromal Tumors. Clinical and Translational Gastroenterology, 11(3), e00156. doi: 10.14309/ctg.0000000000000156.

20. Dhakal, D., Huang, J., \& Shrestha, S. (2019). Case Report of Duodenal Gastrointestinal Stromal Tumor Masquerading a Pancreatic Head Tumor. Yangtze Medicine, 3(4), 271-282. doi: 10.4236/ym.2019.34026.

\section{Clinical and morphological features \\ of gastrointestinal stromal tumors}

I. Yakovtsoval, Ya. Miroshnichenko ${ }^{1}$, T. Chertenko ${ }^{1}$, M. Krotevich ${ }^{2}$ ${ }^{1}$ Kharkiv Medical Academy of Postrgraduate Education

${ }^{2}$ National Cancer Institute, Kyiv

Abstract. Introduction. Gastrointestinal stromal tumors (GISTs) are the most common mesenchymal tumors of digestive system. These tumors have usually indolent course, but in some cases can acquire malignant features. Aim. To investigate the main clinical and morphological features of GISTs with different location. Materials and methods. This study is based on retrospective analysis of case histories, histological samples stained with hematoxylin-eosin and immunohistochemical samples stained with CD117, CD34, DOG1, SMA and CD56 from 100 patients, who were primary diagnosed with GIST and got surgical excision of this tumor in period from 2013 till 2019. The factor of inclusion in group was the ability to get 


\section{Оригінальні статті / Original Articles}

follow up history of the patient within at least a year after surgery. Results. According to site the GISTs divided into GISTs of small intestine (38\%), gastric GISTs (34\%), GISTs of large intestine (27\%) and 1 GIST of esophagus. Epithelioid GISTs were located in stomach only. These tumors were negative to CD34 and focally slightly positive to CD117. Some of them have shown mild expression of CD56 in single tumor cells. Nongastric GISTs have usually spindled morphology. Duodenal GISTs occurred in 5\% of cases and were diagnosed as cancer of the head of pancreas before histology was not performed. Jejunal and ileac GISTs were larger than $5 \mathrm{~cm}$ in $100 \%$ of cases. The main number of advanced GISTs in our study were from this group. More than the half of patients with small intestinal GISTs didn't have any symptoms of disease at all, anemia was found in third of cases. Colorectal GISTs present in $27 \%$ of cases. $92.6 \%$ of these tumors were $<5 \mathrm{~cm}$ and in third of cases associated with other malignancies. All nongastric GISTs demonstrated marked expression of CD117, DOG-1 and in $68.2 \%$ of cases CD34. The mild expression of SMA was found in 12 tumors (12\%). All these GISTs were spindled. Nongastric GISTs have a tendency to relapse in period from 1 till 3 tears oftener than gastric
GISTs. Conclusions. Small intestinal GISTs in our study were usually larger, asymptomatic, but demonstrated more aggressive behavior. Colorectal GISTs were found in our study 5 times more often than in data given by $\mathrm{WHO}$ and third of cases were associated with other tumors. This data can be used for following study of oncogenesis of these group of colorectal GISTs. Almost all nongastric GISTs had spindle cell morphology and showed good expression of CD117 and DOG-1. Epithelioid GISTs were characterized by gastric location, mild focal expression of CD117 and negative reaction to CD34.

Key words: gastrointestinal stromal tumors; epithelioid GISTs; spindle cell GISTs; prognosis; CD117; DOG-1.

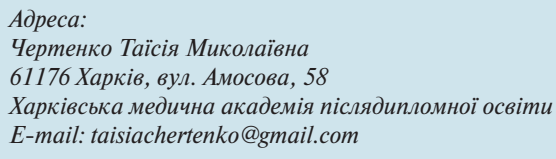
E-mail: taisiachertenko@gmail.com 